\title{
First records of Eocronartium muscicola (Basidiomycota, Eocronartiaceae) in Chile on two new hosts
}

\section{Primeros registros de Eocronartium muscicola (Basidiomycota, Eocronartiaceae) en Chile sobre dos nuevos hospederos}

\author{
Pablo Sandoval ${ }^{1,4}$, José L. Henríquez ${ }^{1}$, Luis Faúndez ${ }^{2,4}$ \& Juan Larraín ${ }^{3}$ \\ 1'Departamento de Sanidad Vegetal y ${ }^{2}$ Departamento de Producción Agrícola, Facultad de Ciencias Agronómicas, Universidad \\ de Chile, Santa Rosa 11315, La Pintana, Santiago, Chile. \\ ${ }^{3}$ Departamento de Botánica, Universidad de Concepción, Casilla 160-C, Concepción, Chile. \\ ${ }^{4}$ BIOTA, Gestión y Consultorías Ambientales Ltda. Roberto Owen 0267, La Florida, Santiago, Chile. \\ agropablo@gmail.com; jhenriqu@uchile.cl; Ifaundez@uchile.cl; juanlarrain@udec.cl
}

\begin{abstract}
The heterobasidiomycete fungus Eocronartium muscicola is an obligate parasite recorded on about 21 moss species, mainly from the Northern Hemisphere. It interacts with its hosts mainly by replacing the sporophyte and obtaining water and nutrients from the gametophyte through specialized tissues. This work reports for the first time E. muscicola on the native mosses Eurhynchium corralense and Eurhynchiella acanthophylla in central and southern Chile, in different forest formations. Also, associations between fungi and bryophytes as well as the taxonomic status of Chilean host mosses and its relationship with E. muscicola are discussed.
\end{abstract}

KEYwords: Pucciniomycetes, Eurhynchiella acanthophylla, Eurhynchium corralense, moss parasite, Chilean Mycobiota.

\section{RESUMEN}

El hongo heterobasidiomycete Eocronartium muscicola es un parásito obligado registrado en alrededor de 21 especies de musgos, principalmente del hemisferio norte. Interactúa con los musgos reemplazando el esporofito y de esta forma aprovechando el flujo de agua y nutrientes que va desde el gametofito a través de tejidos especializados. Este trabajo reporta E. muscicola por primera vez en Chile central y sur con los musgos nativos Eurhynchium corralense y Eurhynchiella acanthophylla en diferentes tipos de formaciones boscosas. Además, se comentan los tipos de relaciones entre hongos y briófitas y se discute el estatus taxonómico de los musgos chilenos hospedantes y su relación con E. muscicola.

Palabras Clave: Pucciniomycetes, Eurhynchiella acanthophylla, Eurhynchium corralense, parásito de musgos, micobiota chilena.

\section{INTRODUCTION}

During floristic surveys in central and southern Chile, whitish, club-shaped sporophores of a basidiomycete were observed growing on the ramifications of different pleurocarpic moss species. Bryophylous fungi are common on mosses, liverworts and hornworts. Taxonomically diverse fungi are found in this associations, especially ascomycetes (Döbbeler 1997, 2002) but also zygomycetes (Thormann et al. 2001), and basidiomycetes such as Eocronartium muscicola (Pers.) Fitzp., Naucoria sphagneti P.D. Orton and Arrhenia retiruga (Bull.) Redhead (Kost 1988). A relationship among lichenized fungi and bryophytes has also been observed, with the lichen Ochrolechia androgyna
(Hoffm.) causing the death of an individual of the moss Hypnum cupressiforme Hedw. (Faegri 1980). Many genera of these fungi are obligate parasites with most of them belonging to the Pezizomycotina (Döbbeler 1997, 2002; Frieders \& McLaughlin 2001). Others live in a symbiotic association similar to the arbuscular mycorrhiza (Schüssler 2000). Nevertheless, the associations between fungi and bryophytes have been scarcely studied from the point of view of morphology, function and ecology (Davey \& Currah 2006) and to date, there have been no reports of bryophylic fungi in Chile. In this study we report for the first time $E$. muscicola in Chile, with a characterization of the native mosses associated. 


\section{MATERIAL AND METHODS}

SAMPLE IDENTIFICATION

The samples were collected and processed according to Rossman et al. (1998) and were documented in situ and in laboratory with a Nikon Coolpix L1, P8 and D90 camera (Nikon, Japan). KOH 3\% and lactophenol blue solution were used for the microscopic characterization through a phase contrast microscope (Axiostar plus, Carl Zeiss, Germany). Fungal taxonomy was based on Kirk et al. (2008), following the nomenclature of Index Fungorum (http://www.indexfungorum.org/Names/Names.asp, access date: May 2011). The data bases for Chilean fungi of Mujica et al. (1980) and Minter \& Peredo (2006) were reviewed. The species of mosses were determined by comparison with herbarium material and following nomenclature of the data base of TROPICOS from the Missouri Botanical Garden (http://www.tropicos.org, access date: May 2011). The specimens collected were deposited in the herbaria of Museo Nacional de Historia Natural in Santiago (SGO). Herbarium abbreviations follow Thiers (2011).

\section{RESULTS}

TAXONOMY AND DESCRIPTION

Eocronartium muscicola (Pers.) Fitzp., Phytopathology 8: 197 (1918).

(Synonyms, see Index Fungorum)

Type location: Sweden.

Chilean specimens, described as follows, correspond well to the descriptions given by Atkinson (1902), Lowy (1971) and Rockett \& Kramer (1973) with simple and erect basidiomata, club-shaped to filiform, white to pale cream colored, with a thin and waxy to sub-fleshy appearance, darkening towards the apex, up to $20 \mathrm{~mm}$ tall and $0.5 \mathrm{~mm}$ diameter (Fig. 1a, 1c); hymenium amphigenous, sterile at the base; heterobasidia differentiating in clavate probasidia and curved metabasidia, becoming transversally triseptate, $65 \times 6 \mu \mathrm{m}$; sterigmata sub-cylindrical to subulate $13 \times 3.5$ $\mu \mathrm{m}$; basiodiospores falcate, 22-30 x 4-7 $\mu \mathrm{m}$, generating secondary spores or germinating by a germ tube (Fig. 1b).

E. muscicola has a wide distribution in both hemispheres, with most records from Northern Hemisphere within Europe and North America (Kirk et al. 2008), although also there are records from Costa Rica (Frieders \& McLaughlin 2001), Argentina, Brazil and Colombia (Lowy 1971, Wright \& Wright 2005).

Chilean mosses as hosts of Eocronartium muscicola

E. muscicola was found parasitizing two different pleurocarpic moss species, Eurhynchiella acanthophylla
(Mont.) M.Fleisch. (Fig. 1c, 1d) and Eurhynchium corralense (Lorentz) A.Jaeger (Fig. 1a), both species placed in the Brachytheciaceae. It should be mention that the collection from comuna de Chaitén was named Eurhynchium cf. corralense, since it has markedly more cordate leaves than the rest of the collections examined. However there is not enough information about the variability of this taxon, and a revision of the genus Eurhynchium in southern South America would be needed for taking further taxonomic conclusions.

Specimens eXamined. CHILE, Región Metropolitana, Maipú, Rinconada de Maipú, Quebrada de la Plata. Parasitizing Eurhynchiella acanthophylla (det. Juan Larraín) on a rock within a forest of Cryptocarya alba (Molina) Looser ('Peumo') and Quillaja saponaria Molina ('Quillay'), lat. 3329'53.89’S, long. 7055’05.05’'O, 765 m s.n.m., leg. L. Faúndez, J.L. Henríquez and P. Sandoval, det. Pablo Sandoval, 24-IX-2009 (SGO 159989). Region de Los Ríos, Futrono, around lake Maihue, parasitizing Eurhynchium corralense (det. Juan Larraín) on a fallen tree in a forest composed mainly of Nothofagus obliqua (Mirb.) Oerst.

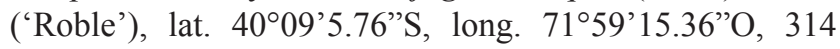
m s.n.m., leg. P. Sandoval, det. Pablo Sandoval, 5-V2010 (SGO 159990); Mafil, near of route 5, parasitizing Eurrhynchium corralense (det. Juan Larraín) on living tree of Myrtaceae species within a Blepharocalyx cruckshanksii (Hook. \& Arn.) Nied. ('temu') forest, lat. 3944'51.91’S, long. 7253'5.92”W, 96 m s.n.m., leg. P. Sandoval, det. Pablo Sandoval, 12-IX-2011 (SGO 160800). Chaitén, side of Austral road, near the lake Yelcho, parasitizing Eurrhynchium cf. corralense (det. Juan Larraín) growing on living plant of Fuchsia magellanica Lam. ('chilco'), within a Laureliopsis philippiana (Looser) Schodde ('tepa') with Nothofagus dombeyi (Mirb.) Oerst. ('coihue') forest, lat. $43^{\circ} 8^{\prime} 15.31$ ”S, long. $72^{\circ} 26^{\prime} 41.39^{\prime}$ 'W, 156 m s.n.m., leg. P. Sandoval, det. Pablo Sandoval, 25-VIII-2011 (SGO 160801).

\section{DISCUSSION}

Eocronartium muscicola in Chile

The examination of the specimens allowed us to identify the fungus as Eocronartium muscicola (Pers.) Fitzp. and although Spegazzini (1887) reported Anthina muscigena Speg. growing on mosses in Puerto Hambre ("Port Famine") near Punta Arenas, Magallanes, which is a basionym of Atractiella muscigena (Speg.) Speg., considered by Lowy (1971) as a synonym of E. muscicola, Spegazzini point out there are not reproductive structures in his collections and he considered it as Mycelia Sterilia. Therefore, we consider this work as the first report of E. muscicola in Chile. 


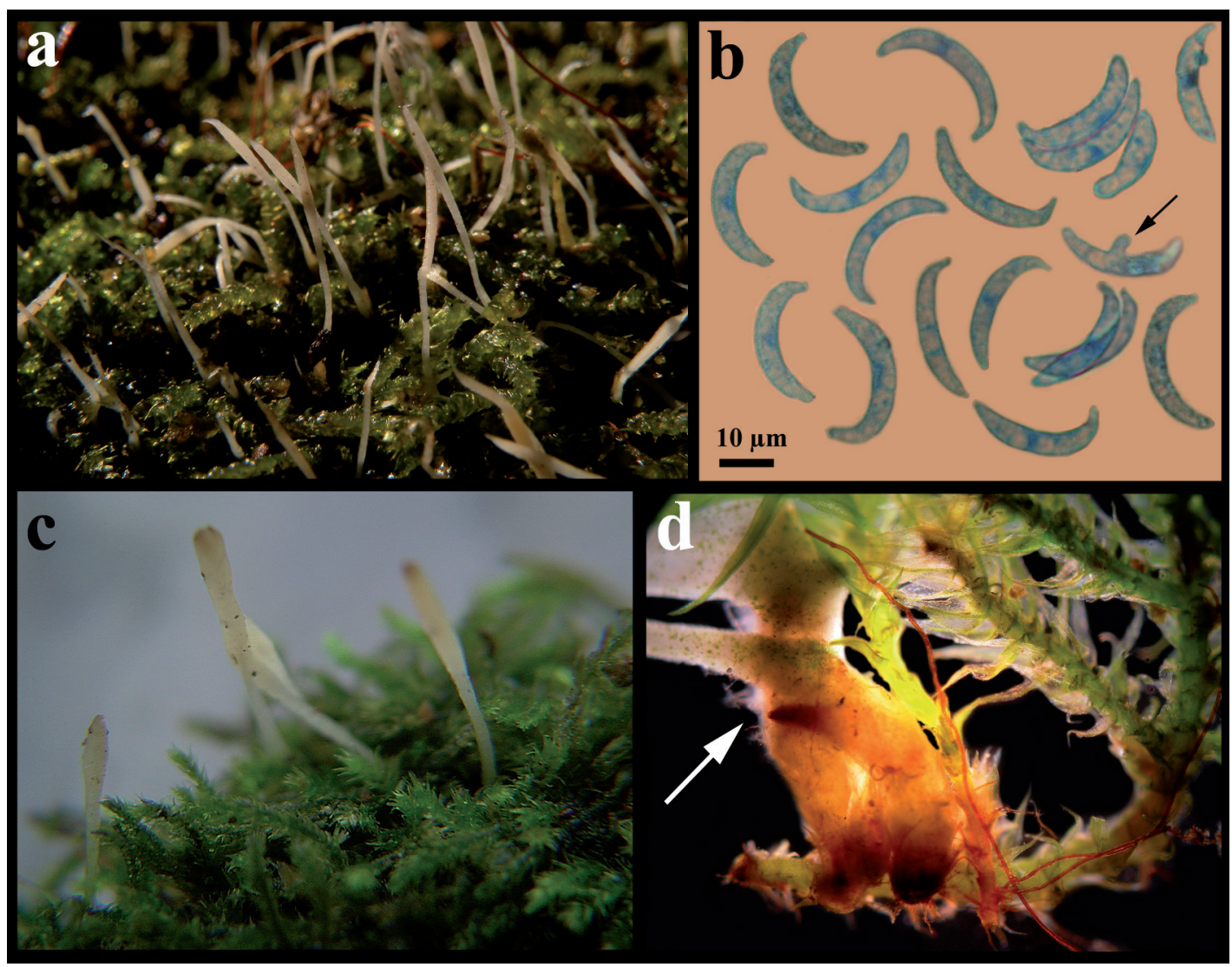

FigURE 1. Eocronartium muscicola: a. General view of basidiomata on Eurhynchium corralense (SGO 159990); b. Basidiospores. Formation of secondary spore (arrow) (SGO 159990); c. General view of basidiomata on Eurhynchiella acanthophylla (SGO 159989); d. Detailed view of the insertion point of the basidiomata on perichaetium of Eurhynchiella acanthophylla (arrow) (SGO 159989).

FigURA 1. Eocronartium muscicola: a. Vista general de los basidiomas sobre Eurhynchium corralense (SGO 159990); b. Basidiosporas. Formación de espora secundaria (flecha) (SGO 159990); c. Vista general de los basidiomas sobre Eurhynchiella acanthophylla (SGO 159989); d. Detalle del punto en que se inserta el basidioma sobre el periquecio de Eurhynchiella acanthophylla (flecha) (SGO 159989).

TAXONOMY AND BIOLOGY OF EOCRONARTIUM MUSCICOLA E. muscicola is an obligate parasite of some 21 species of mosses from different genera and families (Boehm \& McLaughlin 1988). It was originally described by Fitzpatrick (1918) growing on ramifications of Climacium americanum Brid. It belongs to the Eocronartiaceae Jülich (Kirk et al. 2008), order Platygloeales, created to separate those genera with simple pore septa from the Auriculariales (Moore 1990). The order contains mainly phytoparasitic genera including Jola, another moss parasite. The similarity of the basidiomata to those of the genus Cronartium made Atkinson (1902) believe in a close relationship of Eocronartium with rust fungi, which has been recently supported by molecular studies, allowing the placement of Eocronartium in the Pucciniomycetes (Aime et al. 2007).

Boehm and McLaughlin (1988) point out that $E$. muscicola has a unique way of nutrition, as the fungus exploits the nutritive flow passing through the transfer cells of the moss. Also, they observed different levels of biotrophy that could be explained by the diversity of physiological races of the fungus or by genetic differences in the host. The phenology of infection depends on the ability of the moss to generate sporophytes, which can be completely replaced in an earlier stage of development, or the fungus may grow in the apexes of the vegetative ramifications in the case of mosses which rarely form sporophytes.

The parasitized mosses studied presented basidiomata of E. muscicola growing from the perichaetium (Fig. 1d), replacing the sporophyte. Boehm \& McLaughlin (1988), reported a similar association on mosses from the Northern Hemisphere. The fungi of the genus Jola also exploit the transfer cells, but indirectly, being restricted to the capsule of the sporophyte of tropical mosses without replacing it (Boehm \& McLaughlin 1988). 
Characterization AND TAXONOMICAL STATUS OF THE HOST MOSSES

The present study is the first record of E. muscicola parasitizing Eurhynchiella acanthophylla and Eurhynchium corralense, two endemic Chilean mosses. Eurhynchiella acanthophylla is a poorly known species that requires additional studies to clarify its taxonomical status (Crosby et al. 2000). It is common in the lowland forests in central and southern Chile from Choapa to Aysén (Müller 2009, Seki 1974), growing in shady understory on the base of tree trunks and rocks. It was originally described by Montagne (1845) as Hypnum acanthophyllum based on a specimen with unknown collection site collected by Claudio Gay, but later transferred by Fleischer (1923) to the genus Eurhynchiella, characterized by a monoicous sexual condition, creeping stems, straight ovate-lanceolate slightly serrulate leaves, the costa ending at midleaf, and smooth setae. Theriot (1917), when describing the variety robusta, for Rhynchostegiella acanthophylla (Mont.) Broth. (=Eurhynchiella acanthophylla), noted major variability in its size, and in the shape of its leaves and capsules. This strong variability in morphological traits makes it difficult to delimit the taxon, and underlines the current need of a taxonomical revision of this species.

Eurhynchium corralense is a species not present in the mosses checklist of Crosby et al. (2000) and is referred in the literature as Oxyrrhynchium corralense (Lorentz) M. Fleisch. ex Reimers, Rhynchostegium subsquarrosum Herzog or Eurhynchium confusum Thér. (Van der Wijk et al. 1962). All these names are believed to refer to the same species, and due to the lack of a taxonomical monograph of this group for southern South America, we preferred to be conservative and to keep the name E. corralense, also because major variation was observed in the specimens examined from the CONC herbarium and in the collected material parasitized by E. muscicola. This taxon has been reported from Limarí to Osorno (Müller 2009), the records of this taxon, found in "Fuegia australis" (Dusen 1905), correspond to the type species of Sciaromium flavidulum Dusén, actually a synonym of Eurhynchium fuegianum Cardot [fide Matteri \& Ochyra 1989], and not to E. corralense as indicated by Müller. The taxonomy of this genus is also in need of more profound studies.

\section{ACKNOWLEDGMENTS}

The authors wish to thank Víctor Ardiles for collaboration during the development of this work and to Marjorie Correa, Jorge Homero Márquez and Patricio Saldivia for their pertinent comments.

\section{REFERENCES}

Aime, M.C., P.B. Matheny, D.A. Henk, E.M. Frieders, R.H. Nilsson, M. Piepenbring, D.J. McLaughlin, L.J. Szabo, D. Begerow, J.P. Sampaio, R. Bauer, M. Weiss, F. OberwinkLer \& D.S. HibBett. 2007. An overview of the higher-level classification of Pucciniomycotina based on combined analyses of nuclear large and small subunit rDNA sequences. Mycologia 98: 896-905.

Atkinson, G.F. 1902. Preliminary note on two new genera of basidiomycetes. The Journal of Mycology 8(3): 106-107.

Boenm, E.W.A. \& D.J. McLaughlin. 1988. Eocronartium muscicola: a basidiomycetous moss parasite exploiting gametophyte transfer cells. Canadian Journal of Botany 66: 762-770.

Boenm, E.W.A. \& D.J. McLaughlin. 1989. Phylogeny and ultrastructure in Eocronartium muscicola: meiosis and basidial development. Mycologia 81: 98-114.

Crosby, M.R., R.E. Magill, B. Allen \& S. He. 2000. A checklist of the mosses. Missoury Botanical Garden, St. Louis. 320 pp.

Davey, M. \& R. Currah. 2006. Interactions between mosses (Bryophyta) and fungi. Canadian Journal of Botany 84: 1509-1519. doi:10.1139/B06-120.

DöBBeler, P. 1997. Biodiversity of bryophilous ascomycetes. Biodiversity and Conservation 6: 721-738.

DöBbelen, P. 2002. Microniches occupied by bryophilous ascomycetes. Nova Hedwigia 75(3-4): 275-306.

Dusén, P. 1905. Musci nonnulli novi e Fuegia et Patagonia reportati. Botaniska Notiser 1905: 299-310.

FAEGRI, K. 1980. Growth in an Ochrolechia androgyna thallus 1961-1979. Lichenologist 12: 248-250.

FitzPATRICK, H.M. 1918. The life history and parasitism of Eocronartium muscicola. Phytopathology 8: 197-218.

Fleischer, M. 1923. Die Musci der Flora von Buitenzorg. 4: ixxxi, 1104-1729.

Frieders, E.M. \& D.J. McLaughlin. 2001. The heterobasidiomycete moss parasites Jola and Eocronartium in culture: cytology, ultrastructure, and anarmorph. Mycological Research 105(6): 734-744.

Kirk, P.M., P.F. Cannon, D.W. Minter \& J.A. Stalpers. 2008. Dictionary of the fungi. 10th Edition. CAB International, Wallingford. $771 \mathrm{pp}$.

Kost, G. 1988. Moss inhabiting basidiomycetes: Interactions between basidiomycetes and bryophyta. Endocytobiosis and Cell Research 5: 287-308.

Lowy, B. 1971. Tremellales. Flora Neotropica. Vol. 6. New York Botanical Garden Press on behalf of Organization for Flora Neotropica, Hafner, Nueva York. 153 pp.

Matteri, C.M. \& R. Ochyra. 1989. Notes on two southern South American species of Brachytheciaceae (Musci). Journal of the Hattori Botanical Laboratory 66: 321-330.

Minter, D.W. \& H. Peredo. 2006. Hongos de Chile. www. cybertruffle.org.uk/chilfung. Sitio internet, versión 1.00 . Access date: May 2011.

Montagne, C. 1845. Cinquième centurie de plantes cellulaires exotiques nouvelles. Décades I à VI. Annales des Sciences Naturelles, Botanique, Series 3, 4: 86-123. 
Moore, R.T. 1990. Order Platygloeales ord. nov. Mycotaxon 39: 245-248.

Mujica, F., C. Vergara \& E. Oehrens. 1980. Flora Fungosa Chilena. $2^{\text {a }}$ ed., Editorial Universitaria, Santiago de Chile, $308 \mathrm{pp}$.

MülleR, F. 2009. An updated checklist of the mosses of Chile. Archive for Bryology 58: 1-124.

Rockett, T.R. \& C.L. Kramer. 1973. The Tremellales of Kansas. Transactions of the Kansas Academy of Science 76(2): 107-137.

Rossman, A., R. Tulloss, T. O’Dell \& R.G. Thorn. 1998. Protocols for an all taxa Biodiversity Inventory of Fungi in a Costa Rican conservation area. Parkway Publishers, Inc. North Caroline 175 pp.

SCHÜssler, A. 2000. Glomus claroideum forms an arbuscular mycorrhiza-like symbiosis with the hornwort Anthoceros punctatus. Mycorrhiza 10: 15-21.

SEKI, T. 1974. A moss flora of Provincia de Aisén, Chile. Journal of Science of the Hiroshima University, Series B, Div. 2 (Botany) 15: 9-101.

Spegazzini, C. 1887. Fungi Patagonici. Boletín de la Academia
Nacional de Ciencias Córdoba 11: 5-64

StANLEY, I.N. 1940. Development of the Basidium of Eocronartium muscicola. Transactions of the American Microscopical Society. 59(4): 407-413.

THÉRIOT, I. 1917. Contribution a la flore bryologique du Chili $\left(2^{\circ}\right.$ article). Revista Chilena de Historia Natural 21: 6-37.

Thiers, B. [continuously updated]. Index Herbariorum: A global directory of public herbaria and associated staff. New York Botanical Garden's Virtual Herbarium. http://sweetgum. nybg.org/ih. Access date: May 2011.

Thormann, M.N., R.S. CURrah \& S.E. Bayley. 2001. Microfungi isolated from Sphagnum fuscum from a southern boreal bog in Alberta, Canada. Bryologist 104: 548-559. doi:10.1639/0007-2745(2001)104[0548: MIFSFF]2.0.CO;2.

Van der WiJK, R., W.D. Margadant \& P.A. Florschutz. 1962. Index Muscorum. 2 (D-Hypno). Regnum Vegetabile 26: $1-535$.

Wright, J.E. \& A.M. Wright. 2005. Checklist of the Mycobiota of Iguazú National Park (Misiones, Argentina). Boletín Sociedad Argentina de Botánica 40(1-2): 23-44.

Recibido: 06.07.11

Aceptado: 17.11.11 